\title{
TRADISI PABUNCINGAN JERO DONG DING DI DESA PAKRAMAN MUNCAN, KECAMATAN SELAT KABUPATEN KARANGASEM \\ Oleh
}

\author{
Ida Ayu Dwidyaniti Wira
}

Sekolah Tinggi Pariwisata Bali Internasional

dwidyanitiwira88@gmail.com

\begin{abstract}
ABSTRAK
Tradisi Pabuncingan Jero Dong Ding adalah salah satu bentuk tradisi agama yang dipersembahkan dewa yadnya kepada Ida Sang Hyang Widhi Wasa yang dilakukan dengan tujuan menerapkan kesuburan yang disampaikan kepada Ida Sang Hyang Widhi Wasa dalam manifestasinya sebagai Lingga (jero Dong) dan Yoni (Jero Ding ) yaitu aspek Tuhan dalam bentuk simbol Purusa-Pradana dari Dewa Siwa dan Dewi Parwati atau Uma. Berdasarkan analisis ini, dapat disimpulkan sebagai hasil sebagai berikut: Proses implementasi tradisi Pabuncingan Jero Dong Ding di Pakraman Muncan dibagi menjadi tiga tahap: Proses pembuatan, proses Ngelinggihang dan kegiatan Pabuncingan Jero Dong Ding. Alasan penerapan tradisi Jero Pabuncingan Ding Dong, dalam teologi adalah untuk memohon disajikan kepada Ida Sang Hyang Widhi Wasa dalam manifestasi Dewa Siwa dan Dewi Uma, dalam mitologi didasarkan pada kepercayaan atau kepercayaan yang berkembang di masyarakat pedesaan Pakraman Muncan.
\end{abstract}

Kata kunci: Tradisi, Pabuncingan Jero Dong Ding

\section{ABSTRACT}

Tradition Pabuncingan Jero Dong Ding is one form of religious traditions god yadnya devoted presented to Ida Sang Hyang Widhi Wasa conducted with the purpose of applying the fertility presented to Ida Sang Hyang Widhi Wasa in his manifestation as Lingga (jero Dong) and Yoni (Jero Ding) ie aspect of God in the form Purusa-Pradana symbol of Lord Shiva and Goddess Parvati or Uma. Based on this analysis, be concluded as the following results: The process of implementation of the tradition Pabuncingan Jero Dong Ding in Pakraman Muncan divided into three stages: The process of making, the process Ngelinggihang and activities Pabuncingan Jero Dong Ding. The reason for the implementation of the tradition Jero Pabuncingan Ding Dong, in theology is to invoke presented to Ida Sang Hyang Widhi Wasa in manifestation of Lord Shiva and Goddess Uma, in the mythology is based on the belief or confidence that developed in rural communities Pakraman Muncan.

Keywords: Tradition, Pabuncingan Jero Dong Ding

\section{A. PENDAHULUAN}

Tradisi di Bali memang masih bisa tetap bertahan dan masih tetap dilaksanakan oleh masyarakat, akan tetapi makna, tujuan, dan nilai-nilai atau ajaran-ajaran yang terkandung di dalam pelaksanaan tradisi tersebut, semakin lama semakin kabur atau kurang dipahami oleh masyarakat. Seperti halnya masyarakat Hindu di Bali yang cendrung menjalankan suatu tradisi atau ritual secara besar-besaran dan cendrung nampak 
mewah. Kesan mewah tersebut tidak hanya nampak dari sarana upakara yang digunakan melainkan juga dari tata busana umat yang menjalankan tradisi tersebut. Seperti yang diungkapkan oleh almarhum Ida Pedanda Gunung dalam Paruman Agung Dharma Ghosana (Pedanda Siwa-Buddha) Nusantara yang digelar di Pasraman Saraswati Kumuda Sari Griya Ulon, Desa Pakraman Jungutan, Menurut Ida Pedanda Gunung, sedapat mungkin harus diupayakan bisa mencegah upacara adat atau ritual yang jor-joran hanya garagara demi gengsi. Sebab, upacara yang jor-joran itu berdampak terhadap memiskinkan umat. Ida Pedanda Gunung mencontohkan upacara Pitra Yadnya dan Manusia Yadnya yang kerap digelar dengan megah demi gengsi. Yang berat, tentu saja krama (umat) yang mengikuti upacara tersebut. Mereka harus menanggung ongkos sangat besar. Padahal leluhur kita terdahulu mewariskan kita tradisi pasti memiliki tujuan, makna, dan mengandung ajaran-ajaran agama yang patut di laksanakan dan tentunya pada zaman dulu dilakukan secara sederhana tetapi penuh makna dan dilaksanakan dengan rasa tulus ikhlas.

Terkait dengan uraian tradisi di atas, di Desa Pakraman Muncan, Kecamatan Selat, Kabupaten Karangasem memiliki suatu tradisi keagamaan yang khas karena tradisi ini merupakan tradisi yang sudah dilaksanankan secara turun temurun dan sudah dilaksanakan sejak dulu kala yang dikenal dengan dresta desa. Tradisi tersebut oleh masyarakat setempat diberi nama Tradisi Pabuncingan Jero Dong Ding. Tradisi ini dilaksanankan secara rutin setiap tahunnya yakni setiap Tilem Kesanga, saat Pangerupukan atau sehari sebelum hari raya Nyepi. Tradisi ini merupakan upacara pemujaan kepada $I d a$ Sang Hyang Widhi Wasa dalam manifestasi-Nya sebagai Lingga (jero Dong) dan Yoni (Jero Ding) yakni aspek Tuhan dalam wujud Purusa-Pradana perlambang Dewa Siwa dan Dewi Uma atau Parwati.
Pada umumnya, Dewa Siwa dan Saktinya dimuliakan oleh umat Hindu melalui pemujaan di tempat - tempat suci, seperti di mandir atau mandiram, pura, kuil, candi, parahyangan, sanggah, pemerajan, dan yang sejenisnya. Umat Hindu di Bali berkeyakinan bahwa beliau berstana di Puncak Gunung Agung. Sesuai pustaka suci Siwa Purana bahwa beliau dipuja-puji oleh umat Hindu dunia berupa lingga dan yoni. Lingga merupakan lambang dari Dewa Siwa adalah gunung itu sendiri (giri atau parwata) dan yoni, lambang dari dewi Parwati yang merupakan sumber kesuburan dan kearifan.

Akan tetapi, ada hal yang unik dan berbeda dalam melakukan pemujaan kepada Ida Sang Hyang Widhi Wasa dalam manifestasi-Nya sebagai Dewa Siwa dan Dewi Parwati atau Uma di desa Pakraman Muncan, Kecamatan Selat Kabupaten Karangasem. Dimana pemujaan kepada Dewa Siwa dan Dewi Parwati atau Uma dilaksanakan dalam Tradisi Pabuncingan Jero Dong Ding dengan cara menyimbolkan kekuatan Dewa Siwa dan Dewi Uma sebagai aspek purusa-pradana kedalam sepasang arca berwujud laki-laki dan perempuan yang diberi nama Jero Dong dan Jero Ding. Kata Jero Dong Ding mengingatkan bunyi gamelan Selonding yang dulu pernah ada di desa Muncan. Nama lainnya disebut Bhatara Sanga, mungkin karena arca tersebut berlangsung setiap akhir dari sasih Kesanga atau juga Dewata Nawa Sangga yang turun ke dunia dalam wujud sepasang dewa dan dewi yang menganugrahkan kesuburan pada umat manusia Dimana dalam pelaksanaan tradisi Pabuncingan Jero Dong Ding ini memperlihatkan etika hubungan sex yang dapat dilihat oleh seluruh warga desa Muncan, mulai dari anak-anak, remaja, dan orang tua.

Arca atau patung Jero Dong dibuat dari pohon dadap (kayu sakti) bercabang tiga, tinggi sekitar 250 centimeter yang kemudian posisinya dibalik. Dimana bagian pangkal menjadi kepala dan badannya, dua cabang sejajar dijadikan sepasang kaki dan cabang ketiga dijadikan alat 
kelamin (phalusnya) dilengkapi dengan sepasang tangan, wajah dalam keadaan tersenyum dan posisi rambut diikat seperti layaknya rambut seorang pandita (maprucut). Sedangkan arca Jero Ding (yang wanita) dibuat dari pelapah enau menjelang dewasa (jaka dehe) tinggi sekitar 240 centimeter yang juga posisinya dibalik, bagian pangkal sebagai kepala dan badan, sedangkan bagian atasnya sebagai kaki dilengkapi dengan alat kelamin dari bahan yang sama, buah dada dan sepasang tangan, dengan rambut berasal dari ijuk yang menempel pada pelepah enau tersebut, dilengkapi pula dengan hiasan kepala dan wajahnya juga dalam keadaan terseyum. Kedua arca ini menggunakan busana layaknya penganten, menggunakan kain dan kampuh poleng atau yang bercorak loreng (sakordi). Jero Ding dilengkapi denga sebilah keris dipunggungnya.

Pelaksanaan tradisi ini pun sudah mengalami beberapa perubahan yang disesuaikan dengan perkembangan zaman akan tetapi masih mempertahankan pakem atau aturan terdahulu. Seperti yang diungkapkan oleh Bendesa desa Pakraman Muncan Jero Gede Putus Upadesa, Beliau mengungkapkan ada beberapa perubahan dalam pelaksanaan tradisi Pabuncingan Jero Dong Ding ini yang disesuaikan dengan perkembangan zaman. Seperti dari segi bentuk arca yang dibuat lebih seni, anyaman penyengker yang dulunya sederhana hanya menggunakan janur kini terbuat dari papan triplek, serta hiasan-hiasan yang digunakan pun menggunakan hiasan palsu yang lebih awet seperti hiasan rambut arca wanita menggunakan bunga palsu. Akan tetapi menurut beliau, perubahan tersebut tidak menyimpang dari pakem yang ada serta tetap mempertahankan makna dan tujuan dilaksanakannya tradisi tersebut.

\section{B. PEMBAHASAN}

\section{1) Proses Pelaksanaan Tradisi Pabuncingan}

\section{Jero Dong Ding di Desa Pakraman Muncan}

Prosesi adalah rangkaian pelaksanaan suatu upacara yang biasa dilaksanakan dalam setiap upacara keagamaan yang juga dilaksanakan oleh hampir seluruh umat manusia di dunia dengan segala bentuk, corak, dan ragam prosesi tersebut. Demikian juga halnya dengan prosesi Tradisi Pabuncingan Jero Dong Ding di Desa Pakraman Muncan yang memiliki beberapa tahapan dalam proses pelaksanaannya. Prosesi tradisi Pabuncingan Jero Dong Ding diawali dengan pembuatan arca Jero Dong dan Jero Ding.

Arca Jero Dong dan Jero Ding merupakan dua buah arca yang dibuat sebagai simbol Purusa dan Pradana. Proses pembuatan kedua arca tersebut dimulai tiga hari nemu beteng setelah upacara Ngusaba Petung di desa Pakraman Muncan dan harus sudah selesai atau jadi 21 hari sebelum hari Pengerupukan (Tilem Kesanga). Proses pembuatan kedua arca tersebut selama 7 hari. Adapun proses pembuatannya diawali dengan upacara nunas taru atau kayu yang akan digunakan sebagai bahan pembuatan kedua arca di sekitar lingkungan desa. Adapun jenis kayu yang digunakan adalah kayu sakti (kayu dapdap) yang bercabang tiga untuk arca laki-laki Jero Dong. Kayu sakti tersebut memiliki panjang sekitar 250 centimeter yang kemudian posisinya dibalik. Dimana bagian pangkal menjadi kepala dan badannya, dua cabang yang sejajar dijadikan sepasang kaki dan cabang yang ketiga dijadikan alat kelamin phalusnya) dilengkapi dengan sepasang tangan, wajah dalam keadaan tersenyum dan posisi rambut diikat seperti layaknya rambut seorang pandita (maprucut).

Arca perempuan Jero Ding dibuat dari pelepah pohon enau menjelang dewasa (jake dehe) tinggi sekitar 240 centimeter yang juga posisinya dibalik, bagian pangkal sebagai kepalanya dan badan, sedangkan bagian atasnya sebagai kaki. Arca Jero Ding juga dilengkapi dengan alat kelamin dari bahan yang sama, buah dada, dan sepasang tangan, dengan rambut berasal dari ijuk yang menempel pada pelepah enau tersebut, dilengkapi pula dengan hiasan kepala. Kemudian kedua arca ini dipakaikan busana layaknya sepasang pengantin dengan menggunakan kain dan saput poleng atau yang bercorak loreng (kain sakordi). 
Jero Dong juga dilengkapi dengan sebilah keris dipunggungnya. Adapun lokasi pembuatan kedua arca tersebut yaitu di Pura Puseh. Yang ditugaskan membuat arca Jero Dong Ding adalah seorang undaggi di desa yang memiliki pemahaman tentang tattwa dan undagi tersebut dipilih oleh desa. Adapun proses pembuatan arca Jero Dong Ding dapat dilihat pada gambar 5.1 dibawah ini:

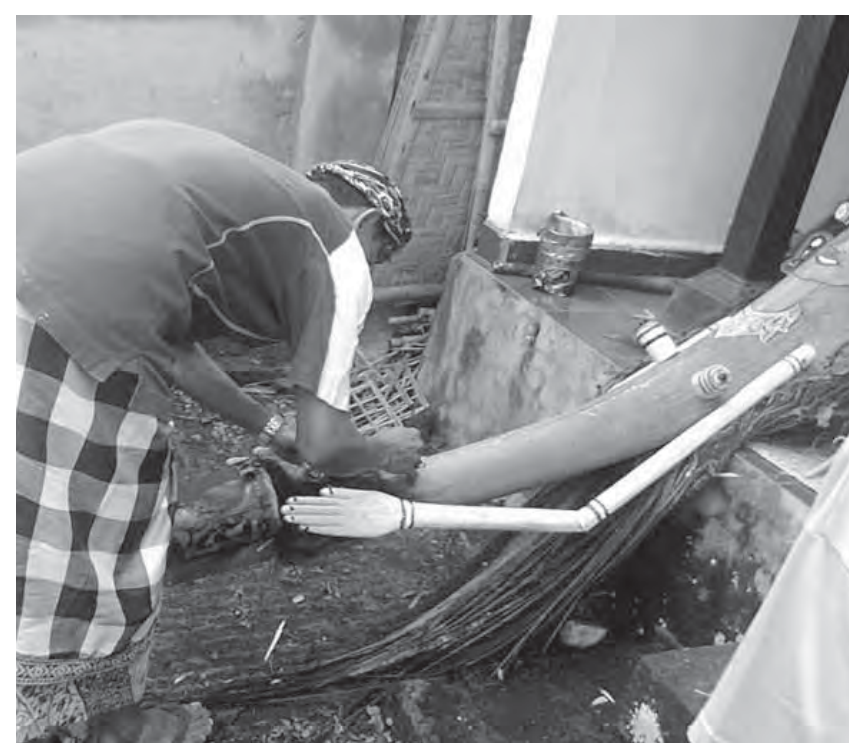

Gambar 5.1

\section{Proses Pembuatan Arca Jero Dong Ding}

Setelah arca Jero Dong Ding selesai dibuat, selanjutnya arca Jero Dong Ding distanakan di catus pata dengan menggunakan sarana upakara Pemelaspasan dan diupacarai perkawinan dengan sarana upakara Pabhyakala (natab banten beten) tepatnya menjelang 21 hari sebelum hari Pengerupukan (Tilem Kesanga) yang dipuput oleh Pemangku Pura Puseh. Setelah arca Jero Dong Ding diupacarai, selanjutnya kedua arca distanakan tepat pada catus pata Desa Pakraman Muncan. Dimana arca Jero Dong Ding tersebut distanakan dengan dibuatkan sejenis pelinggih yang lengkap dengan tembok penyengker (pembatas) yang terbuat dari anyaman daun kelapa, dihiasi seperti pelinggih lengkap dengan lelontekan dan tedungnya. Kemudian arca Jero Dong Ding distanakan pada tempat tersebut selama 21 hari dan selama 21 hari tersebut dihaturkan banten perayunan. Adapun gambaran arca Jero Dong Ding distanakan di Catus Pata dapat dilihat pada gambar 5.2 dibawah ini:

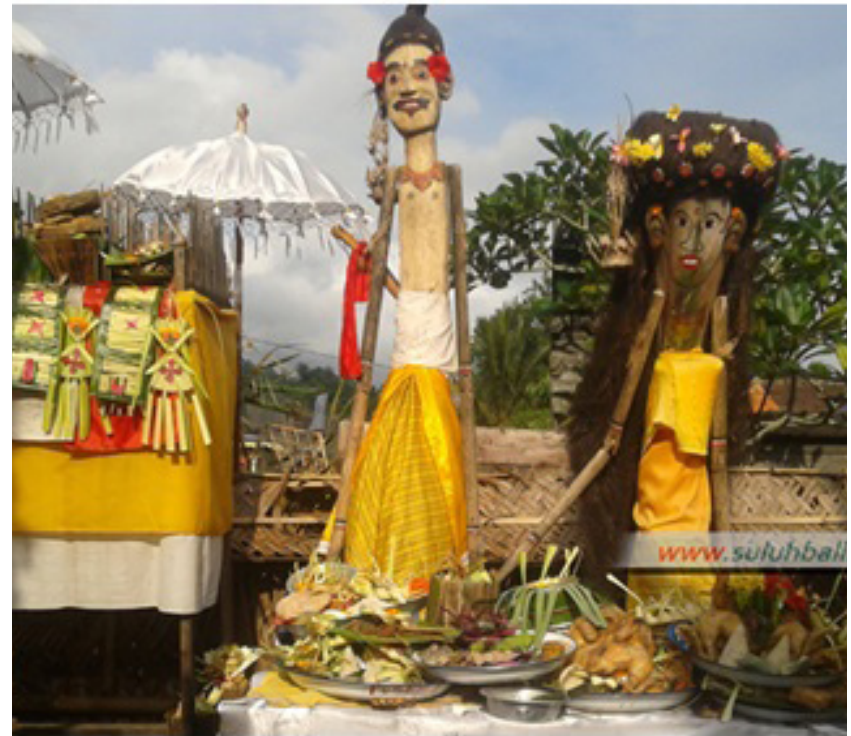

Gambar 5.2

Arca Jero Dong Ding distanakan di Catus Pata

Kata pabuncingan berasal dari Bahasa Bali dimana menurut Kamus Bahasa Bali (Budha Gautama.2009:97), kata pabuncingan berasal dari akar kata "buncing" mendapat awalan padan akhiran -an sehingga menjadi pabuncingan yang berati upacara perkawinan. Ditinjau secara etimologi, perkawinan berasal dari kata "kawin" yang artinya menikah, cak bersetubuh. Kata kawin mendapat awalan pe- dan akhiran -an sehingga menjadi perkawinan artinya pernikahan, hal yang berurusan dengan kawin. Puncak dari pelaksanaan tradisi Pabuncingan Jero Dong Ding yaitu pada hari Tilem Kesanga yaitu setiap Pengerupukan (sehari sebelum hari raya Nyepi). Tradisi itu dilaksanakan setelah upacara bhuta Yadnya Caru Tabuh Gentuh, yang dipusatkan di Catus Pata, Desa Pakraman Muncan.

Tradisi Pabuncingan Jero Dong Ding dipusatkan di Catus Pata (perempatan desa), Desa Pakraman Muncan dimana tradisi Mabuncing diawali dengan melakukan upacara bhuta Yadnya Caru Tabuh Gentuh, menjelang usai upacara ini dilanjutkan dengan kedua arca Jero Dong Ding diupacarai dengan upakara Masakapan (widiwidana). Sebelum prosesi "persetubuhan" itu berlangsung, terlebih dulu Bendesa adat di desa Pakraman Muncan, memukul kulkul, yang panjangnya mencapai 6 meter, dengan garis tengah 99 centimeter. Kulkul yang ada di Pura 
Puseh setempat, secara khusus dibunyikan saat prosesi upacara tersebut. Untuk memukulnya pun, dengan jumlah yang sudah ditentukan. Makna memukul kulkul, kita memberitahu kepada warga, sebagai perintah atau komando, bahwa inilah simbol kehidupan yang harus diikuti, bagaimana dalam perkawinan, mengarungi kehidupan dengan tapa brata yoga semadi.

Usai memukul kulkul itu, barulah ke acara puncak, yang memang ditunggu-tunggu oleh masyarakat setempat, yaitu prosesi "perkawinan" Purusa-predana. Dimana simbol Purusa - Predana yang lengkap dengan alat kelamin masing-masing itu dikawinkan, layaknya orang bersetubuh. Upacara ini dilaksanakan oleh Bendesa dan pemangku puseh yang berjumlah 7 orang yang biasa disebut mangku pitu serta dibantu oleh prajuru desa lainnya. Seorang diantara pemangku tersebut mengangkat Jero Dong dan yang lainnya mengangkat Jero Ding dengan menyikap kain masing-masing, dengan memasukkan phalus ke dalam vagina sehingga menampakkan adegan layak sensor. Adegan orang dewasa ini disaksikan oleh sebagian besar masyarakat desa Muncan, baik anak-anak dan orang dewasa, laki-laki maupun perempuan dengan iringan sorak sorai menyaksikan acara yang unik ini. Selesai upacara Mabuncing, kedua arca tersebut di-prelina (dimatikan secara ritual) selanjutnya diarak mengelilingi desa sebanyak 3 kali dengan arah prasvya (kebalikan jalan arahnya jarum jam) menuju alam kematian. Kemudian kedua arca tersebut dihanyutkan bersama ogoh-ogoh di sungai Yeh Sah Telaga Waja. Saat pengerupukan adalah hari terakhir atau puncak acara.

Adapun sarana atau upakara yang digunakan saat arca Jero Dong dan Jero Ding dibuncingkan adalah berupa Banten tumpeng 7, Banten Catur dan 2 buah banten Bebangkit dan kapuput oleh Sulinggih atau Pinandita serta saat nganyut atau melarung Jero Dong Ding pun menggunakan sarana upakara pejati. Adapun Proses Pabuncingan Jero Dong Ding dapat dilihat pada gambar dibawah ini:

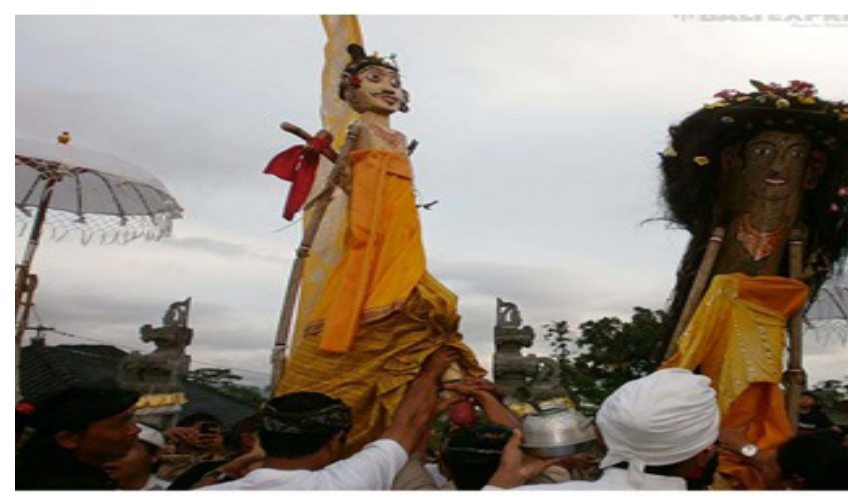

Gambar Prosesi Pabuncingan Jero Dong Ding

\section{2) Alasan dilaksanaannya Tradisi Pabuncingan Jero Dong Ding di Desa Pakraman Muncan}

Tradisi merupakan adat istiadat, ritus-ritus, ajaran-ajaran sosial, pandangan-pandangan, nilainilai, aturan-aturan, perilaku dan sebagainya yang diwariskan dari generasi ke generasi. Ia merupakan warisan sosio kultural yang dilestarikan dalam masyarakat atau dalam kelompok-kelompok sosial masyarakat dalam kurun waktu panjang. Menurut (Lorens Bagus, 2002:115-116). Tradisi merupakan suatu hal atau kegiatan yang berupa kebiasaan yang telah diwariskan secara turun-temurun dari leluhur terdahulu yang hingga kini masih terus dilaksanakan oleh kelompok masyarakat tertentu dan masih terjaga kelestariannya.

Begitu pula dengan tradisi Pabuncingan Jero Dong Ding di Desa Pakraman Muncan yang merupakan tradisi keagamaan yang sudah dilaksanankan secara turun temurun dan sudah dilaksanakan sejak dulu kala oleh masyarakat desa Pakraman Muncan yang sudah menjadi dresta desa. Suatu tradisi masih tetap lestari dan masih dilaksanakan dari dulu hingga sekarang, pasti didasari oleh keyakinan masyarakat di desa tersebut. Sama halnya dengan tradisi Pabuncingan Jero Dong Ding yang masih tetap terjaga kelestariannya. Tradisi Pabuncingan Jero Dong Ding di Desa Pakraman Muncan masih tetap dilaksanakan dari dulu hingga sekarang dikarenakan krama desa percaya dan meyakini tradisi tersebut. hal tersebut ditunjukkan dari antusiasme masyarakat ketika melaksanakan tradisi tersebut. Adapun alasan atau latar belakang dilaksanakannya Tradisi Pabuncingan Jero Dong 
Ding di Desa Pakraman Muncan dibagi menjadi dua unsur yakni secara Teologi (Ketuhanan) dan secara Mitologi (mitos).

\section{a. Unsur Teologis}

Dalam Wikipedia bahasa Indonesia Teologi berasal dari bahasa Yunani "theos", yang berarti Allah, Tuhan, dan "logia", yang berarti kata-kata, ucapan, atau wacana. Wacana yang dimaksud adalah wacana yang berdasarkan nalar mengenai agama, spiritualitas, dan Tuhan. Dengan demikian, teologi adalah ilmu yang mempelajari segala sesuatu yang berkaitan dengan keyakinan beragama. Teologi meliputi segala sesuatu yang berhubungan dengan Tuhan. Selanjutnya dalam kamus filsafat disebutkan teologi secara sederhana yaitu suatu studi mengenai pertayaan tentang Tuhan dan hubungannya dengan dunia realitas. Dalam pengertian yang lebih luas, teologi merupakan salah satu cabang dari filsafat atau bidang khusus inquiri filosofi tentang Tuhan (Runes,1953:317). Teologi atau dalam bahasa sansekertanya Brahmawidya atau Brahma Tattwa Jnana adalah ilmu tentang Tuhan (Pudja, 1984:14).

Unsur teologi pada tradisi Pabuncingan Jero Dong Ding di Desa Pakraman Muncan yaitu pada aspek Ketuhanan atau dewa yang dipuja dalam pelaksanaan tradisi tersebut. Tradisi Pabuncingan Jero Dong Ding merupakan tradisi keagamaan yang dilaksanakan dengan tujuan memohon kesuburan kehadapan Ida Sang Hyang Widhi Wasa dalam manifestasi-Nya sebagai Lingga (jero Dong) dan Yoni (Jero Ding) yakni aspek Tuhan dalam wujud Purusa-Pradana perlambang Dewa Siwa dan Dewi Parwati. Tradisi Pabuncingan Jero Dong Ding di Desa Pakraman Muncan dilaksanakan untuk memohon kesuburan kehadapan Ida Sang Hyang Widhi Wasa dalam wujud dua buah patung Jero Dong dan Jero Ding sebagai simbol PurusaPradana perlambang Dewa Siwa dan Dewi Uma atau Dewi Parwati. Kesuburan yang dimaksud tidak hanya dalam wujud kesuburan padi di sawah ataupun tanaman yang ada di lingkungan desa, akan tetapi kesuburan yang dimaksud merupakan kesuburan dan kemakmuran bagi seluruh aspek kehidupan yang ada di desa Pakraman Muncan baik itu tumbuh-tumbuhan, ternak, dan kehidupan masyarakat desa. Banyak krama desa yang datang dan ikut menyaksikan pelaksanaan tradisi Pabuncingan Jero Dong Ding dengan harapan agar memiliki keturunan, hubungan yang harmonis, dan murah rejeki.

Seperti yang diungkapkan oleh Ida Ayu Tary Puspa (2012) dalam artikel yang berjudul "Ardanareswari Dalam Hindu" beliau mengungkapkan ajaran agama Hindu yakni dalam Siwa Tattwa dikenal konsep Ardhanareswari yaitu simbol Tuhan dalam manifestasi sebagai setengah purusa dan pradana. Kedudukan dan peranan purusa disimbolkan dengan Siwa sedangkan Pradana disimbolkan dengan Dewi Parwati atau Dewi Uma. Di dalam proses penciptaan, Siwa memerankan fungsi maskulin sedangkan Dewi Uma memerankan fungsi feminim. Tiada suatu apa pun akan tercipta jika kekuatan purusa dan pradana tidak menyatu. Penyatuan kedua unsur itu diyakini tetap memberikan bayu bagi terciptanya berbagai mahluk dan tumbuhan yang ada.

Makna simbolis dari konsep Ardhanareswari, kedudukan dan peranan perempuan setara dan saling melengkapi dengan laki-laki bahkan sangat dimuliakan. Tidak ada alasan serta dan argumentasi teologis yang menyatakan bahwa kedudukan perempuan berada di bawah lakilaki. Itulah sebabnya di dalam berbagai sloka Hindu dapat ditemukan aspek yang menguatkan kedudukan perempuan di antara laki-laki. Hal tersebut juga tercantum dalam kitab Manawa Dharmasastra I.32 dimana dalam Manawa Dharmasastra I.32 disebutkan:

\section{Dwidha kartwatmanodeham \\ Ardhena purusa bhawat \\ Ardhena nari tasyam sa \\ Wirayama smrjat prabhuh}

\section{Terjemahannya:}

Tuhan membagi dirinya menjadi sebagian laki-laki dan sebagian menjadi

perempuan (ardha nari). Darinya terciptalah viraja (Pudja dan Sudharta, 2004:9).

Sloka di atas menegaskan bahwa lakilaki dan perempuan sama-sama diciptakan oleh Tuhan. Laki-laki dan perempuan menurut pandangan Hindu memiliki kesetaraan karena keduanya tercipta dari Tuhan. Dengan demikian, maka perempuan dalam Hindu bukan merupakan 
dibawah kedudukan dari laki-laki. Demikian pula sebaliknya. Kedua makhluk yang berbeda jenis kelamin ini memang tidak sama. Perbedaan tersebut adalah untuk saling melengkapi. Tuhan menciptakan laki-laki dan perempuan juga diungkapkan dalam kitab Manawa Dharmasastra, dimana kitab Manawa Dharmasastra IX.96 menyebutkan sebagai berikut:

\section{Prajanartha striyah srtah \\ Samtanartam ca manawah \\ Tasmat saharano dharmah \\ Srutao patnya sahaditah}

\section{Terjemahannya:}

Tujuan Tuhan menciptakan wanita, untuk menjadi ibu. Laki-laki diciptakan untuk menjadi ayah. Tujuan diciptakan suami istri sebagai keluarga untuk melangsungkan upacara keagamaan sebagaimana ditetapkan menurut Veda (Pudja dan Sudharta, 2004:462).

Dari konsep Ardhanariswari tersebut mengisyaratkan bahwa perempuan memiliki kedudukan yang setara dengan laki-laki. Perempuan dalam teologi Hindu bukanlah tanpa arti. Malahan dia dianggap sangat berarti dan mulia sebagai dasar kebahagiaan rumah tangga. Di dalam Yajurveda (XIV.21) dijelaskan bahwa perempuan adalah perintis, orang yang senantiasa menganjurkan tentang pentingnya aturan dan dia sendiri melaksanakan aturan itu. Perempuan adalah pembawa kemakmuran, kesuburan, dan kesejahteraan, sebagaimana tertera pada Yajurveda, XIV. 21 berikut:

\section{Murdha asi rad dhuva asi}

Daruna dhartri asi dharani

Ayusa twa varcase tva krsyai tva ksemaya twa

\section{Terjemahannya}

Oh perempuan engkau adalah perintis, cemerlang, pendukung yang memberi makan dan menjalankan aturan-aturan seperti bumi. Kami memiliki engkau di dalam keluarga untuk usia panjang, kecemerlangan, kemakmuran, kesuburan pertanian, dan kesejahteraan.

Perempuan adalah ciptaan Tuhan dalam fungsinya sebagai pradana. Ia juga disimbolkan dengan yoni, sumber kesuburan dan kearifan. Laki-laki ciptaan Tuhan dalam fungsi sebagai purusa yang disimbolkan dengan lingga. Oleh karena perempuan juga, maka berbagai bentuk persembahan akan terlaksana, karena perempuan pula ketenangan dan ketentraman akan terwujud.

Berdasarkan pemaparan di atas dapat disimpulkan bahwa dalam konsep purusapradana ini, maka alasan dilaksanakannya tradisi Pabuncingan Jero Dong Ding di Desa Pakraman Muncan secara teologi adalah untuk memohon kehadapan Ida Sang Hyang Widhi Wasa dalam manifestasi-Nya Dewa Siwa dan Dewi Uma dengan menyimbolkan pertemuan unsur Purusa dengan Pradana dengan harapan terciptanya kesuburan dan kemakmuran bagi seluruh aspek kehidupan yang ada di desa Pakraman Muncan. Memuja Ida Sang Hyang Widhi Wasa dalam aspeknya sebagai Purusa untuk memohon kekuatan untuk dapat mengembangkan hidup yang bahagia secara rohaniah, sedangkan memuja Tuhan sebagai Pradana adalah untuk mendapatkan kekuatan rohani dalam membangun kehidupan jasmani yang sehat dan makmur.

\section{b. Unsur Mitologi (Mitos)}

Dalam Wikipedia bahasa Indonesia, istilah "mitologi" dapat berarti kajian tentang mitos . Mitos adalah kisah suci yang biasanya menjelaskan bagaimana dunia maupun manusia dapat terbentuk seperti sekarang ini. Mitologi berkaitan dengan legenda maupun cerita rakyat. Mitologi dapat mencakup kisah penciptaan dunia sampai asal mula suatu bangsa. Tidak seperti mitologi, pada cerita rakyat, waktu dan tempat tidak spesifik dan ceritanya tidak dianggap sebagai kisah suci yang dipercaya kebenarannya. Sedangkan pada legenda, pelaku-pelakunya adalah manusia dan meskipun kejadiannya dianggap benar-benar terjadi, dapat mengandung kisah makhluk supranatural (dewa, setan) dan kejadian luar biasa (kutukan, keajaiban) seperti pada mitologi.

Adapun unsur mitologi yang melatarbelakangi dilaksanakaannya tradisi Pabuncingan Jero Dong Ding di Desa Pakraman Muncan yaitu masyarakat mempercayai apabila tradisi ini tidak dilaksanakan, maka bencana akan melanda desa. Masyarakat di desa Pakraman Muncan dari dulu meyakini apabila tradisi Pabuncingan Jero Dong Ding di Desa Pakraman Muncan tidak 
dilaksanakan maka akan terjadi paceklik desa. Hal itu pernah terbukti ketika terjadi erupsi Gunung Agung pada tahun 1963 yang berlangsung hampir satu tahun. Pada tahun tersebut, tradisi ini tidak dapat dilaksanakan oleh masyarakat setempat sehingga desa mengalami kekeringan, hama tikus menyerang, dan gagal panen. Hal tersebut diyakini oleh masyarakat terjadi tidak hanya karena unsur alam akan tetapi juga karena tidak dilaksanakannya tradisi Pabuncingan Jero Dong Ding. Karena hal itulah, sejak tahun 1964 sampai dengan sekarang tradisi tersebut masih tetap dilaksanakan oleh masyarakat setiap tahunnya.

Berdasarkan penjelasan dari Bendesa Desa Pakraman Muncan tersebut, maka dapat disimpulkan alasan dilaksanakannya tradisi Pabuncingan Jero Dong Ding di Desa Pakraman Muncan secara mitologi adalah berdasarkan keyakinan atau kepercayaan yang berkembang di masyarakat desa Pakraman Muncan apabila tradisi ini tidak dilaksanakan, desa akan mengalami kutukan berupa bencana kekeringan yang mengakibatkan terjadinya paceklik desa seperti kekeringan, hama tikus menyerang, dan gagal panen.

\section{PENUTUP}

Berdasarkan uraian tentang tradisi Pabuncingan Jero Dong Ding di Desa Pakraman Muncan, Kecamatan Selat Kabupaten Karangasem yang telah dipaparkan di atas, maka ada beberapa hal yang patut digarisbawahi sebagai sebuah kesimpulan sebagai berikut:

Proses pelaksanaan tradisi Pabuncingan Jero Dong Ding di Desa Pakraman Muncan terbagi dalam tiga tahapan yaitu 1) Proses pembuatan Arca Jero Dong dan Jero Ding, 2) Proses Ngelinggihang Jero Dong Ding, dan 3) Kegiatan Pabuncingan Jero Dong Ding. Alasan pelaksanaan tradisi Pabuncingan Jero Dong Ding di Desa Pakraman Muncan yaitu 1) Unsur Teologi (Ketuhanan) adalah untuk memohon kehadapan Ida Sang Hyang Widhi Wasa dalam manifestasi-Nya Dewa Siwa dan Dewi Uma dengan menyimbolkan pertemuan unsur Purusa dengan Pradana dengan harapan terciptanya kesuburan, 2) Unsur Mitologi adalah keyakinan atau kepercayaan yang berkembang di masyarakat apabila tidak melaksanakan tradisi
Pabuncingan Jero Dong Ding maka desa akan mengalami bencana kekeringan atau paceklik.

\section{DAFTAR PUSTAKA}

Atmaja, I Made Nada, dkk. 2010. Etika Hindu. Surabaya: Paramita.

Bagus, Loren. 2005. Manusia dan Kebudayaan Indonesia. Jakarta: Gramedia.

Djelantik, A.A.M. 1990. Pengantar Dasar Ilmu Estetika Jilid I Estetika Instrumental. Denpasar: Sekolah Tinggi Seni Indonesia (STSI) Denpasar.

Ghazali, Adeng Muchtar. 2011. Antropologi Agama Upaya Memahami Keragaman Kepercayaan, Keyakinan, dan Agama. Bandung: Alfabeta.

Kajeng, I Nyoman. 1997. Sarasamuccaya Dengan Teks Bahasa Sanskerta dan Jawa Kuna. Surabaya: Paramita.

Sukardana, K.M. 2009. Panca Sraddha Lima Keyakinan Umat Hindu. Surabaya: Paramita.

Suwardani et al. 2012. Pedoman penulisan usulan skripsi. Denpasar: Pustaka Larasan.

Swastika, I Dewa Gede. 2006. Murdha Citta Dalam Sarasehan Bidang Agama Adat dan Budaya. Denpasar: Badan Diklat Provinsi Bali.

Pudja,G dan Rai Sudharta. 2004. Manava Dharmasastra (Manu Dharmasastra) atau Veda Smerti Compendium Hukum Hindu. Surabaya: Paramita.

Puspa, Ida Ayu Tary. 2012. "Ardanareswari Dalam Hindu". Majalah Hindu Online, (akses tanggal 19 Juli 2016). Tersedia dalam URL: http:// majalahhinduraditya.blogspot.co.id/2012/04/ ardanareswari-dalam-hindu.html. 